\title{
Concerning the unbearable whiteness of urban farming
}

\author{
Antonio Roman-Alcalá* \\ San Francisco, California
}

Submitted to JAFSCD August 19, 2015 / Published online September 18, 2015

This commentary was originally written in 2010 for a newsletter of the San Francisco Bay Area-based food justice organization Planting Justice (http://www.plantingjustice.org). It is reprinted with minor edits with permission.

Citation: Roman-Alcalá, A. (2015). Concerning the unbearable whiteness of urban farming. Journal of Agriculture, Food Systems, and Community Development, 5(4), 179-181. http://dx.doi.org/10.5304/jafscd.2015.054.031

\begin{abstract}
Based on the author's experience in urban agriculture projects and organizations in the United States, this commentary offers some basic, initial, and practical suggestions for how activists who are white or otherwise of relative privilege can approach "food justice" activism in ways that avoid re-inscribing white supremacy, and can more likely achieve the potential of transformative and multiracial urban agriculture movements.
\end{abstract}

\section{Keywords}

urban agriculture, race, identity, strategy, practitioner reflection

\footnotetext{
* Antonio Roman-Alcalá had no institutional affiliation at the time of writing this commentary. He can be contacted at 3027 Harrison Street; San Francisco, California 94110 USA; +1-415-571-6660; antidogmatist@gmail.com

Antonio Roman-Alcalá is an urban farming educator, permaculture designer, scholar of food systems and social movements, musician, and father. He enjoys (organic) ice cream. See more at www.antonioromanalcala.com
}

耳irst off, let me start by stating who I am. I am - a native of San Francisco, California, born to two U.S. citizens. My ethnic background includes Mexican Mestizo, Eastern European Jew, and (like many younger people) smaller parts from all over the world. However, from an outsiders' perspective, I could easily be considered "white." This is the frame that I bring with me: growing up as Latino in a Latino neighborhood, but losing much of that background to the ease of being white. I have, in part, grown into my name being pronounced "Ant-oh-knee-oh" instead of "Ant-ohnyo."

That said, I identify strongly as an antiracist activist. Not meaning that I am not racist, or still struggling with issues of race, but that I strive within my life to question, address, and confront the ongoing oppressions we all experience in a white supremacist world.

My entry into the world of food justice organizing, through my work at Alemany Farm (in San Francisco), was unavoidably steeped in these sorts of issues. But how I go about my work, and 
my perspective on the complexities of race politics, have changed much since that period. I now see a much more complicated picture, and not one that is simply rosy when it comes to being a whiteidentified person working for justice with or in communities of color. And it seems like an increasingly unfunny joke to note that most people working in the sustainable/fair/green/organic/ local/urban food production world are white.

There is no way I could posit a solution to this joke, or make it somehow funnier, but I hope to at least offer one perspective on it.

What guides me still are words attributed to Aboriginal artist Lilla Watson:

If you have come here to help me, you are wasting our time.

If you have come here because your liberation is bound up with mine, then let us work together.

Black, White, Latino, whomever: we are all subject to the whims and injustices of an exploitative, inhumane, and grossly unsustainable capitalist system. While in the present moment, we must acknowledge that having certain attributes (lighter skin color, upper class status, higher education, male gender) can lead to more resources and opportunities (and that the long-touted American Dream is but a mirage for many sectors of the U.S. population), we must also see that "No one is free when others are oppressed." This goes for the "poor" folks in West Oakland as well as the "middle class" folks attending the University of California at Berkeley. Besides a minute percentage of the population who do not have to work for a living, we are all survivors of a broken system, and it is incumbent on us to find ways to challenge this system together.

I prefer not to blame anyone who has started on a path towards food justice activism, simply because they are white. The important question is how they go about that activism. What are some methods and strategies for being an antiracist food justice activist, working to change the norm of a white-dominated food sustainability scene? Here are some ideas to start with:
1. Go to where people are at, not where you want them to be. Stay far away from "knowing what is best for people." If people in your neighborhood don't care about growing food, don't force it. Maybe people feel more excited about an after-school program teaching photography to youth? If so, try to integrate your food-based ideas into programs that the community actually wants. Unite your interests with those of whom you work with; don't patronize.

2. At the same time, don't accommodate people to the extent of ignoring your own needs, desires, strengths or personal mental health. While we must acknowledge the role of people's internalized oppression and racism, and the "problem" behaviors that come from it, giving license to someone to act anti-socially, because of their skin color, is just another form of racism. Likewise, do not deny that you want to address food issues, if that is your passion.

3. Don't operate from assumptions. This is general life advice, of course, but goes especially for activism. For instance, the naïve notion many new food justice activists have that "if only they [read: poor, black/brown people] knew about where their food came from, they would make better choices." Maybe this is true, for some people. But if your goal is to change and improve people's lives, you must start by asking folks what that change would look like, and what it might take to accomplish it. Maybe a central concern is not for organic food, but for having more time to cook? Maybe having a better income would allow for more freedom in food spending habits? Consider the possibility that a local grocery store might be more helpful than 15 community gardens...

4. Always be focused on leadership development. One of the main problems for antiracist whites is that they do not like being treated as, well, white people. In many marginalized communities and communities of color there can be a lot of (justified) resentment and distrust of outsiders (those seen as "others" or part of the dominant elite). While we should work to break down these barriers over time, perhaps more importantly, we must use whatever privilege we have to support the capacity of these communities to 
work for themselves. Youth especially love to be taught by someone who looks like them, and so, if you are interested in being of service to a community that doesn't look like you, train the trainers. Work toward your own position being obsolete.

5. Within group processes, always be conscious of how privileges may be affecting group dynamics (but once again beware of overaccommodation to the point of being patronizing). Simple strategies like effective, shared facilitation, and checking in with each participant to make sure they feel heard, do wonders for the efficacy and longevity of any project. The operative words for white, male, rich, or otherwise privileged activist: step back.

6. Do not downplay, and even more, CELEBRATE non-white contributions to food justice. Many events that I go to about urban farming tend to be homogenously white. But I know that, around the country (and of course the world!), people of color are leading the charge for socially relevant farming. Growing Power's Will Allen is a beacon; as is Boston's Food Project, whose leadership over time came to better reflect the populations it served. Los Angeles's South Central Farmers represent the agrarian vitality of Central American migrants to the U.S., while in the Bay Area People's Grocery and the Richmond Eco-Village are both led by people of color. We can also learn something from the Asian immigrant community, some of whom (the Hmong) are among the best urban farmers in California. In many cases, Asian neighborhoods (with just as low incomes as other "food desert" areas) manage to have thriving food markets and healthy family diets. We all have something to learn from each other, and we must be careful not to downplay or denigrate any particular ethnic or racial group's ownership over the concept of universal access to food that is good, clean, fair, affordable, and delicious. 